\title{
ALA/ACRL Representatives at Academic Ceremonies and Meetings
}

Throughout the year, the American Library Association and the Association of College and Research Libraries receive invitations to a variety of academic ceremonies and meetings. During the past year, members of ALA and ACRL have represented the association at commencement activities, at inaugurations of college and university presidents, at dedications of new libraries, and at annual meetings of other associations.

In June 1973 Emery Wimbish, Jr., librarian of Vail Memorial Library at Lincoln University, in Pennsylvania, represented ALA/ACRL at the commencement activities of that university.

In August 1973 the late Kenneth H. Fagerhaugh, who was director of university libraries at Carnegie-Mellon University, attended the inauguration of Cecil Harland Underwood as thirteenth president of Bethany College. Richard J. Talbot, director of libraries at the University of Massachusetts, in Amherst, represented the association at the inauguration of Darcy Coyle as third president of Nichols College, in Dudley, Massachusetts. Representing ALA. ACRL at the inauguration of John D. Rockefeller, IV, as twelfth president of West Virginia Wesleyan College was Dr. Robert F. Munn, director of libraries at the University of West Virginia, in Morgantown. On October 10, 1973, Dr. Robert J. Greene, librarian of Kennesaw Junior College, in Marietta, Georgia, served as the ALA/ACRL representative at the inauguration of Allen O. Jernigan as president of Reinhardt College, in Waleska, Georgia. Dr. Paul H. Spence, librarian at the University of Alabama, attended the October inauguration of W. Clyde Williams as tenth president of Miles College, in Birmingham. Donald K. Nelson, director of libraries at Brigham Young University, represented the association at the November 19 inauguration of David Pierpont Gardner as president of the University of Utah. On May 28, 1974, Robert J. Adelsperger, special collections librarian at the University of Illinois, Chi-

ACRL Membership

April 30, 1974

12,015

April 30, 1973

11,404

April 30, 1972

10,872

cago Circle Campus, attended the inauguration of James $H$. Mullen as second president of Northeastern Illinois University, in Chicago.

On November 16, 1973, Lewis C. Naylor, librarian of the Toledo-Lucas County (Ohio) Library, served as the association's representative at the dedication of the William S. Carlson Library at the University of Toledo.

In October 1973 Donald C. Anthony, associate director of libraries at Columbia University, and Dr. Beverly P. Lynch, executive secretary of ACRL, attended the fifty-sixth annual meeting of the American Council on Education. Clarence W. Rodgers, senior librarian at Queens Borough (New York) Public Library, and Nancy K. Smith, librarian of the Fels Center of Government at the University of Pennsylvania, attended the seventy-eighth annual meeting of the American Academy of Political and Social Science, held in Philadelphia on April 5 and 6, 1974.

\section{YOU WILL HAVE- "GDNFIDENGE"}

In Our Complete Periodicals ServiceAll American and Foreign Titles
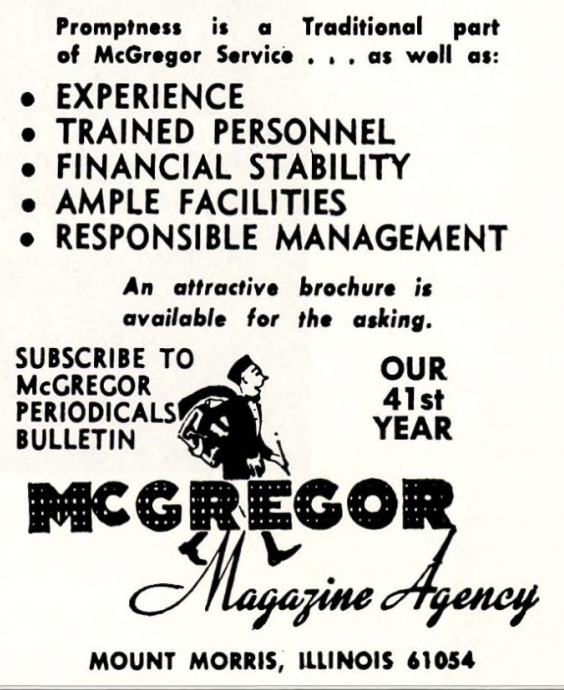
Reprinted at last in 106

\section{Full-Size Bound Volumes!}

MONTHLY

CATALOG

OF UNITED STATES

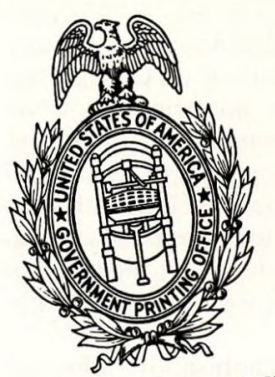
GOVERNMENT PUBLICATIONS

NOVEMBE MAN

Number 754

Now that Cumulative Subject

Access and 30 years of

previously missing SuDocs

Class Numbers have been added,

every library with a serious

interest in government documents

should have the complete set!

OFFERED IN MONEY-SAVING SETS

OR AS SINGLE VOLUMES 


\section{THE MONTHLY CATALOG OF U.S. GOVERNMENT PUBLICATIONS, 1895-1962}

\section{Made even more valuable by ...}

... the availability of the 15 volume Cumulative Subject Index to the Monthly Catalog of U.S. Government Publications,. 1900-1971 which, when used with the Monthly Catalogs for that period, function together as a self-contained documents reference system; and

. . . the addition of more than 100,000 SuDocs Class numbers for 1895-1924, by Mary Elizabeth Poole, author of Documents Office Classification (Fourth Edition, 1974). This effort makes our reprint set the only single printed source of all these numbers for the period from the establishment of the Office of the Superintendent of Documents (in 1895) to the present.

\section{Announcing a unique new concept in reprint publishing:}

Free microfilm sets of the Monthly Catalog will be provided for interim use until all reprint volumes are delivered. Here is a new kind of offer to those librarians who want to record their orders for Monthly Catalog sets now at our pre-publication prices and discounts, but who don't want to wait months for delivery of the complete sets. Immediately upon receipt of your order for our complete reprint edition or its subsets, we'll send you free microfilm copies of those Monthly Catalogs which you ordered. What's more, you can keep these reels of $16 \mathrm{~mm}$ microfilm (valued at more than $\$ 500.00$ for the full run) and continue using them as an extra back-up set after your reprint volumes have arrived. The microfilm for Set I (covering 1895-1924) however does not include the added class numbers.

Here are the 1974 delivery schedules and pre-publication prices of the Monthly Catalog reprints and their Cumulative Subject Index. Yes, you can order single volumes to fill gaps in your holdings . . . see below:

To: Carrollton Press, Inc., 1647 Wisconsin Avenue, N.W., Washington, D.C. 20007

Please record our orders for the following:

The complete reprint edition of the Monthly Catalog of U.S. Government Publications 1895-1962 in 106 hardcover volumes including the thirty volume "Classes Added" Set (1895-1924) plus, at no extra charge, the entire run on 43 reels of $16 \mathrm{~mm}$ microfilm. Postpaid in North America (See delivery dates listed below) $\$ \mathbf{5 , 5 7 0 . 0 0}$

Note: Libraries already having ordered the microfilm set from us may deduct $10 \%$ ( $\$ 557.00)$ from the purchase price.

$\square$ SET I. The "Classes Added" set, 1895-1924, in 30 hardcover volumes with Superintendent of Documents Classification Numbers Added by Mary Elizabeth Poole. Includes microfilm reels for interim use which do not contain Class Numbers (June through December 1974)

SET II. 1925-1935, in 22 volumes with free microfilm (June 1974)

SET III. 1936-1944, in 18 volumes with free microfilm (August 1974) -..-- \$915.00

Individual hardcover volumes of the Monthly Catalog "Classes Added" set) @ \$68.00 each (one volume covers an entire year).1925-1962@\$55.00 per volume (each volume covers $1 / 2$ year, either January through June or July through December).

Cumulative Subject Index to the Monthly Catalog of U.S. Government Publications 1900-1971 15 volumes, clothbound. Postpaid in North America $\$ 965.00$
The Complete Monthly Catalog Reprint Project, 1895-1962.

The Classes Added set, 1895-1924

The Cumulative Subject Index to the Monthly Catalog, 1900-1971 


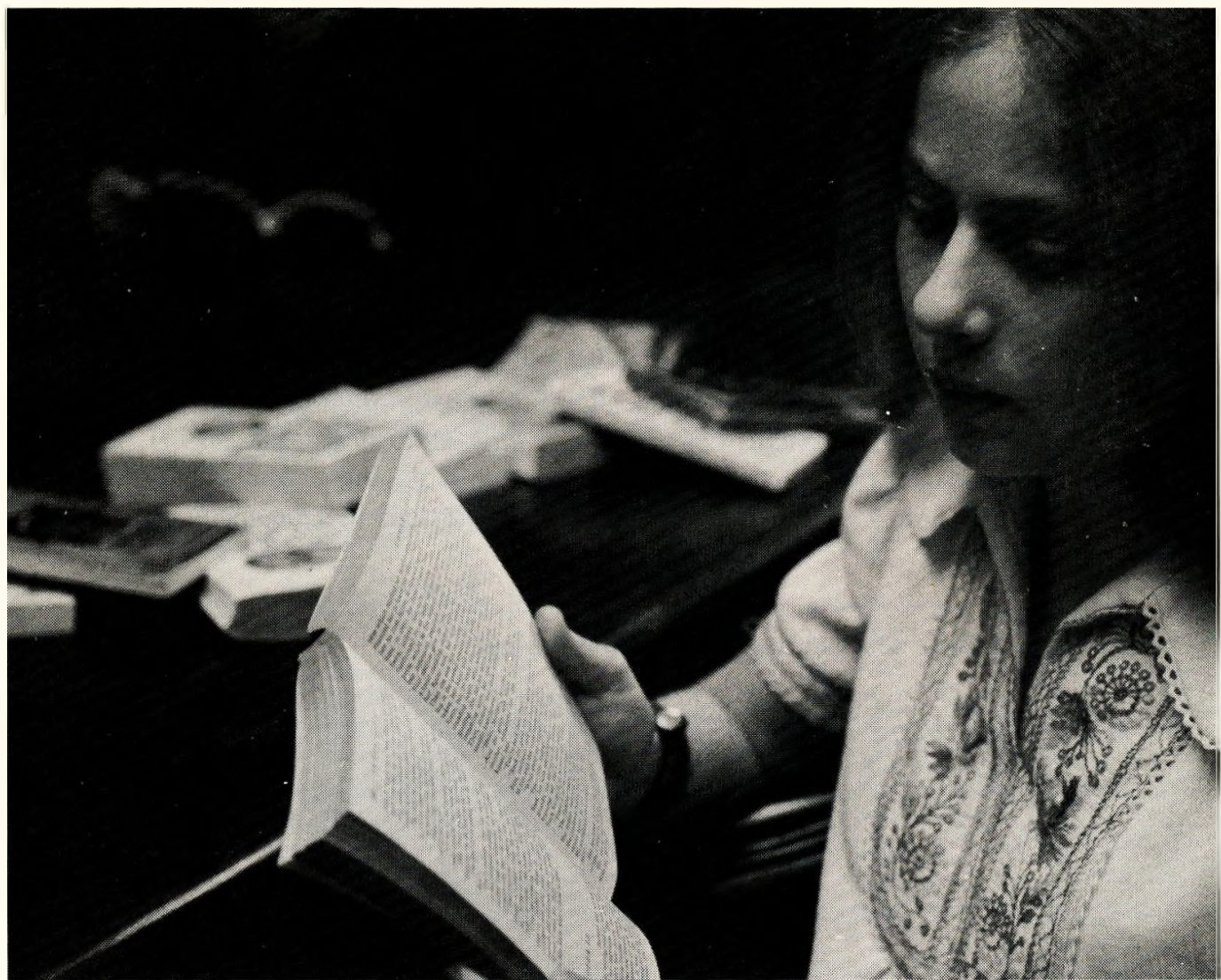

\section{FILL YOUR PAPERBACK NEEDS} through Baker \& Taylor's new, expanded paperback service

Now your library can get mass market and juvenile paperbacks as quickly as higher-priced paperbacks and hardbound books from Baker \& Taylor.

Choose from thousands of titles available for immediate delivery from over five regional book service centers. Our inventory of paperbacks has been vastly expanded to meet the growing demand for paperbacks in all libraries - elementary, secondary, public and academic.

Baker \& Taylor's new paperback service allows you to buy economically. You can buy more titles - and more copies of each title - because you receive generous discounts on these lower-priced paperbacks.

For additional information on our paperback book service, send for our free brochure or contact your Baker \& Taylor representative. Or order your paperbacks now through your regional Baker \& Taylor book service center. Whenever possible please submit separate orders for paperbacks and hardbound books.

\section{The Baker \& Taylor Co.}

\section{EASTERN DIVISION}

SOMERVILLE, NEW JERSEY 08876

50 Kirby Avenue, Tel: 201-722-8000

N.Y. City Tel: $212-227-8470$

SOUTHEAST DIVISION
COMMERCE, GEORGIA 30529
Tel: $404-335-5000$
Atlanta Area
Tel: 0 -WX-5555

SOUTHEAST DIVISION

Tel: 404-335-5000

Tel: 0.WX-5555
MIDWEST DIVISION

MOMENCE, ILLINOIS 60954

Gladiola Avenue

Tel: $815-472 \cdot 2444$

Chicago Tel: 312.641-3233

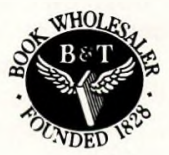

SOUTHWEST DIVISION CLARKSVILLE, TEXAS 75426

Industrial Park Tel: $214-427-3811$

STERN DIVISION RENO, NEVADA 89502 380 Edison Way Tel: $702-786-6700$

Inspection Center for Books and Media: 5820 Wilshire Blvd., Los Angeles, California 90036, Tel: 213-938-2925 Audio Visual Services Division: Box 230, Momence, Illinois 60954, Tel: 815-472-2444 